\section{BMJ Paediatrics Open}

\title{
How has the pandemic changed healthcare for children and young people in the UK?
}

\author{
Sashank Uday
}

To cite: Uday S. How has the pandemic changed healthcare for children and young people in the UK? BMJ Paediatrics Open 2022;6:e001401. doi:10.1136/ bmjpo-2021-001401
Check for updates

(C) Author(s) (or their employer(s)) 2022. Re-use permitted under CC BY-NC. No commercial re-use. See rights and permissions. Published by BMJ.

Oxford, UK

Correspondence to Sashank Uday; sashankuday@ gmail.com
Over the last year, the pandemic has forced a significant paradigm shift in the way the National Health Service (NHS) operates. This pandemic has acted as a catalyst for rapid innovation including the large-scale adoption of virtual appointments. Now is the time to reflect on how best to focus these new developments to propel our healthcare system forward and meet the needs of children.

The State of Child Health 2020 report clearly outlined the priorities reported in a survey of children and young people across the UK. ${ }^{1}$ The three key areas were: exercise and hobbies, quality food and drink, and healthy living. The pandemic has had a significant impact on all these aspects which can be grouped under three main issues. First, the problem of health inequalities has been greatly exacerbated over the lockdown period. Compared with children in the South of England, those living in the North overall lost more education and were predicted to lose $70 \%$ more in lifetime earnings. Second is the lack of preventative measures to reduce avoidable diseases. For example, lack of physical activity and increased snacking during lockdown has resulted in lower fitness levels and increased risk of obesity. Finally, there has been an increase in behavioural problems and deterioration of mental health causing even more pressure on the already strained teenage mental health services.

The voice of children and young people is often not included in conversations about their health. This can lead to feelings of helplessness which was only exaggerated by the pandemic with many children feeling powerless. One avenue to empower and engage children is through organisations such as RCPCH \&Us, of which I am a member. RCPCH \& Us was set up by the Royal College of Paediatrics and Child Health to promote the involvement of children and young people across the UK in decisions relating to their healthcare. ${ }^{2}$ I

\section{My suggestions}

Ensure young people are actively involved in consultations (whether online or face to face)

- For young people in the UK, sign up to the RCPCH \& Us newsletter (https://www.rcpch.ac.uk/ work-we-do/rcpch-and-us/sign-up).

- For young people/healthcare professionals outside the UK, consider how to involve young people in healthcare.

have had the chance to speak in Parliament promoting the State of Child Health 2020 report and highlighting the priorities for children to policymakers. This role gave me the power to work for real change in the healthcare system and made me feel empowered and heard. This is an opportunity that should be widely available for other children from diverse social and ethnic backgrounds through local NHS organisations.

The involvement of children and young people not only democratises healthcare by putting power in the patients' hands but also promotes health awareness and taking ownership of their health. During virtual consultations, children can feel left out and not listened to. During the Royal College of Paediatrics and Child Health (RCPCH) Annual Conference 2021, I had the opportunity to advocate for the active involvement of children in virtual consultations. Children and young people typically have high technological proficiency and so online resources and consultations are intuitive. Schools could provide facilities for children to join online consultations directly from school reducing time away from school. Online surveys could be promoted through the channels of social media to help generate feedback. Additionally, monthly online patient forums where any child or young person can come and share desires or issues could help generate 
discussion among peers and help enhance dialogue between healthcare professionals and patients. Linking to online resources and support groups for chronic conditions such as diabetes allows patients to share their experiences with peers and may improve self-management of their health problems. This may empower the children and give them more independence to make informed decisions regarding their own care and manage their health in the future.

This pandemic, despite its issues, has allowed us to integrate technology into the fabric of our society and has provided us with a crucible in which we can forge a new world where children and young people are more involved in their care. The RCPCH \&Us model is something other countries could adopt to enhance their quality of healthcare and is something that is vital to patient-centred care. This is a unique moment for the NHS to evolve and capitalise on the gains made by involving children and young people more in their care.

Contributors SU wrote this manuscript independently.
Funding The authors have not declared a specific grant for this research from any funding agency in the public, commercial or not-for-profit sectors.

Competing interests None declared.

Patient and public involvement Patients and/or the public were not involved in the design, or conduct, or reporting, or dissemination plans of this research.

Patient consent for publication Consent obtained from parent(s)/guardian(s).

Provenance and peer review Commissioned; internally peer reviewed.

Open access This is an open access article distributed in accordance with the Creative Commons Attribution Non Commercial (CC BY-NC 4.0) license, which permits others to distribute, remix, adapt, build upon this work non-commercially, and license their derivative works on different terms, provided the original work is properly cited, appropriate credit is given, any changes made indicated, and the use is non-commercial. See: http://creativecommons.org/licenses/by-nc/4.0/.

ORCID iD

Sashank Uday http://orcid.org/0000-0002-6316-5262

\section{REFERENCES}

$1 \mathrm{RCPCH}$. State of child health, 2020. Available: https:// stateofchildhealth.rcpch.ac.uk/ [Accessed 29 Dec 2021].

$2 \mathrm{RCPCH}$. RCPCH \& Us. Available: https://www.rcpch.ac.uk/work-wedo/rcpch-and-us [Accessed 30 Dec 2021]. 